ELK ASIA PACIFIC JOURNAL OF SOCIAL SCIENCE

ISSN 2394-9392 (Online); DOI: 10.16962/EAPJSS/issn. 2394-9392/2015; Volume 5 Issue 1 (2018)

\title{
ADI-SHANKARACHARYA'S ADVAITA-VEDANTA PHILOSOPHY: A VIABLE SOLUTION TO ENVIRONMENTAL DISHARMONY WITH SPECIAL REFERENCE TO ANIMAL CRUELTY
}

\author{
VANDANA SHARMA \\ JRF-Indian Council of Philosophical Research \\ Ph.D Research Scholar-Advaita Vedanta \\ Department of Philosophy, \\ Annamalai University, Annamalai Nagar, \\ Tamil Nadu
}

\begin{abstract}
:
Keeping in mind the philosophy of Adi Shankaracharya, this paper aims to throw light on the insensitivity we have developed towards our environment, in particular animals who are as much divine in their essence as humans. This paper in specific wants to divert attention of the profound scholars, professors, philosophers and academicians in regards to the torture animals go through across the lengths and breadths of the globe for satisfying human's desire for food, fashion and fun or merely being a scapegoat to human frustration, failures and setbacks. On a macro level this paper aims to improve the condition of animals and environment by stressing upon the philosophy of
\end{abstract}

Adi-Shankaracharya that professes everything to be the non-dual Brahman.

Keywords: Advaita-Vedanta, Adi-Shankaracharya, Environmental Disharmony, Animal Cruelty,

Non-Dualism

\section{INTRODUCTION:}

Mahatma Gandhi, said:

"To my mind, the life of a lamb is no less precious than that of a human being... I hold that the more helpless a creature is, the more entitled it is to protection..."

George Angell, who walked this planet in the 18th-century was an animal advocate. Once, the media asked him as to why he focuses so much of his time, attention and energies on animals when so much of human barbarism existed. George Angell replied, "I am working at the roots." This statement concludes the

effect that animal savagery has on our environment. Animal cruelty includes a wide range of behaviors including animal hoarding, neglect, abandonment, animal fights, animal rapes and deliberate acts of

\footnotetext{
${ }^{1}$ Animals and World Religions, Lisa Kemmerer, Pg-60
} 


\section{ELK ASIA PACIFIC JOURNAL OF SOCIAL SCIENCE}

ISSN 2394-9392 (Online); DOI: 10.16962/EAPJSS/issn. 2394-9392/2015; Volume 5 Issue 1 (2018)

cruelty. Whatever form it takes, animal cruelty tends to be the starting point for a much wider range of problems from domestic violence, environmental issues, dipping morals and spiritual values to terrorism, social unrest, rapes and a variety of social evils.

According to PETA (People for Ethical Treatment of Animals), a study that was conducted by the Northeastern University and the Massachusetts Society for the Prevention of Cruelty to Animals found that people who committed crimes against animals were five times more likely to commit violence socially. Domestic violence and animal cruelty are also linked. According to the National Institute of Mental Health and Allied Sciences, India, people who are abusive and violent towards animas are likely to be violent towards one's partner, parents, society and environment in general.

Abused children are also more likely to abuse animals than those children who were brought up with love and lessons of brotherhood towards all lives. Vardhaman Institute of Mental Health and Allied Sciences accepts that those who rape and disrespect women and children have at some point abused animals or have been destructive towards environment in general.
Animal cruelty certainly adds to the global issues of environment at a magnified rate. $\mathrm{Be}$ it factory farming that harms our environment by production of excess pollution and injecting animals with high intensity antibiotics and oxytocine to the global meat industry that has massive environmental impacts with contribution of $18 \%-51 \%$ of greenhouse gasses and gulping up of resources that already are short in supply in accordance to a study conducted by the Curtin University, Australia.

In 2016, the World Economic Forum published a report, according to which by the year 2050 the world's oceans would have more plastics than fishes. At present, $32 \%$ of the world's plastic ends up in the ocean and less than $10 \%$ ends up being recycled. Plastic kills millions of animals annually, from fishes, turtles and sea birds to street dogs, cows and cats. Not only that, but it also spreads harmful algae, invasive species and man-made pollutants, which are finally introduced into the food chain. Besides which a plastic takes 800 years to decompose.

There are greater issues that we are facing that come under the wings of animal cruelty and environmental exploitation from climate change, global warming, acid rains, steroid induced milk, low quality soil, hormone injected vegetables, extinction of species to 


\section{ELK ASIA PACIFIC JOURNAL OF SOCIAL SCIENCE}

ISSN 2394-9392 (Online); DOI: 10.16962/EAPJSS/issn. 2394-9392/2015; Volume 5 Issue 1 (2018)

abandoning animals, using them as objects of pleasure and inhuman torture. From cutting down trees and building sky scrapers to harming the flora and fauna in the most inhumane fashion are nothing but episodes of harming our earth.

Advaita-Vedanta philosophy which is rich and all embracing can certainly end all ecological issues and cases of animal cruelty provided it is understood in the right light. It is important that children are introduced to this philosophy at an early age in order to make sure that they grow up to be environmentally conscious and sensitive citizens

\section{ADVAITA-VEDANTA,ENVIRONMENT AND ANIMALS:}

Advaita Vedanta believes in complete sociocultural harmony. Reverence for nature and unity of all is the summum bonum of the Advaita-Vedanta Philosophy. AdvaitaVedanta is one of the 6 orthodox schools of Indian philosophy that considers the Vedas to be the final authority. The other revered texts of this system are BrahmasutraBhashya, Bhagwad-Gita and Upanishads which collectively are known as the Prasthantrayi. Advaita-Vedanta considers the Brahman to be the only reality. Brahman is considered to be indescribable. It is beyond names, forms, time, space and thought. Any effort to describe it is merely trying to bring it down to the level of human interpretation. The self or the Atman in Advaita-Vedanta is synonyms with the Brahman. Atman-Brahman is identical just as the wave and the ocean. Hence, behind the veil of various names and forms exists one ultimate reality called the Brahman or the Atman. The Rig Veda, states-

'Ekam Sat VipraBahuda Vadanti'1

\section{.....That ultimate truth is one, known by the wise} as many.

The distinction of varied names and forms arises due to what is called Maya, Avidya or the cosmic illusion. It is due to the grip of Maya that we see distinction between a bowl, a glass and a flower pot which are essentially made of the same stuff -'mud'. Similarly, due to cosmic illusion we consider men, women, animals, trees, rivers etc as distinct forgetting that in their essence; they are all the nondualBrahaman, for nothing exists outside the Brahman.

Shankara, who is popularly said to be born in the $8^{\text {th }}$ century $\mathrm{BC}$, was a philosopher and metaphysist of the highest order. He was born

\footnotetext{
${ }^{1}$ The Rig Veda. $1-144-116$
} 


\section{ELK ASIA PACIFIC JOURNAL OF SOCIAL SCIENCE}

ISSN 2394-9392 (Online); DOI: 10.16962/EAPJSS/issn. 2394-9392/2015; Volume 5 Issue 1 (2018)

in the southern part of India in a village called Kaladi in the state of Kerala. His logic and reasoning remains unparallel till this date. Jagadguru, as he is fondly called, mastered the Vedas at the age of 4 , completed his

Shankaracharya. At the age of 16 he wrote the Brahmasutrabhashya. He travelled bare feet 4 times across India including Nepal in order to spread the light of Advaita-Vedanta. He also stopped human and animal sacrifices and brought about unity in the society which was at that point divided into various sects by the virtue of his razor sharp logic and philosophical debates with 84 different sects. He also reformed the society by establishing the authority of Jiñana Kanda (Knowledge) over mindless rituals (Karma Kanda). Knowledge here must not be confused with education or gathering of information. Knowledge here refers to realization of self as the non-dual, ultimate reality. Liberation in Advaita-Vedanta is a state where one realizes the self through $\boldsymbol{J} \tilde{\boldsymbol{n}} \overline{\boldsymbol{a}} \boldsymbol{n} \boldsymbol{a}$ as the supreme reality. He wrote several of the most magnificent texts and at the age of 32, he gave up his material body at the holy adobe of Kedarnath in the Himalyas.

Human beings consider themselves to be the most superior and lordly. This thought is education by the age of 7 and became an ascetic monk at the age of 8 . He found his Guru Govind Bhagwadpad along the Narbada river at Omkareshwara, Madhya Pradesh in India. By the time he was 12; he

became an Aacharya and was now called triggered by the western domination theory according to which humans have all the rights to dominate nature, animals and the entire creation for the sake of their benefit, pleasure and entertainment. Such a thought is also promoted by Abrahamic religions like

Christianity and Islam, which consider soul to be exclusive to humans while any creation other than human is meant for mankind's benefit and gratification. It is due to this dualistic approach that we consider something or someone to be separate from us and thus, issues such as superiorityinferiority, appreciation-repulsion, violence, rapes, social intolerance, casteism, religion and cruelty against fellow humans and animals emerge as universal evils.

The Stanford encyclopedia of philosophy describes environmental ethics as:

"A discipline of philosophy that studies the moral relationship between the human and the non-human world" 


\section{ELK ASIA PACIFIC JOURNAL OF SOCIAL SCIENCE}

ISSN 2394-9392 (Online); DOI: 10.16962/EAPJSS/issn. 2394-9392/2015; Volume 5 Issue 1 (2018)

If we carefully look at the definition, we see a distinction between human and that which has been labeled as non-human. Such definitions gave rise to the concepts of environmental preservation, preserving wild life, forests and many more. These concepts arise not on the basis of un-conditionality or as a sense of oneness but as a sense of greed and fear. These concepts clearly see the environment and animals to be distinct from the self and the effort to preserve them is made only under the fear and compulsion to avoid situations like exertion of natural resources, preserving animals for the sake of tourism, economy, entertainment and pleasures. This thought is certainly not nature centric but is human and human greed centric.

Contrary to the western thought, Indian Philosophy and particularly Advaita-Vedanta sees no distinction between man and nature in its very essence. The earth, animals, birds, trees and others have never been seen as objects to be dominated or exploited. Since, Brahman the supreme reality is omnipotent, omnipresent and omniscient; it logically cannot be exclusive to humans alone. Hence, the supreme reality in Advaita-Vedanta is the ground of the entire universe from the heavenly bodies like the sun, moon and earth to the minutest of species like the ants, snakes and tortoise. It is the base of the elements of earth, water, fire, sky and ether to the birds that fly, the puppies that play and the flowers that bloom audaciously. This explains why in India people worship trees, rivers, animals, birds and humans. This supreme reality is non-exclusive and non particular and even extends to what modern science may call as 'non-living'. This also explains as to why in India people till today worship tools, machinery, stones.

It's not that an Indian is superstitious or is bound to forms; it is just that an Indian has a deep sense of understanding that despite varied names and forms there is one divine

force behind all- 'The Brahman'. In the Holy Bhagwad Gita, Lord Krishna says:

"An enlightened one is he who sees me in the wise, in a cow, in a dog, in an elephant, in an ant and in an outcast". ${ }^{1}$

Hence, Advaita-Vedanta doesn't consider a human to be particular, instead it sees him as a general part of nature that is suppose to function as per Dharma. Dharma here must not be confused with religion. Dharma in

\footnotetext{
${ }^{1}$ The Holy Bhagwad Gita, Ch-5, 18, Gita Press, Gorakhpur

${ }^{2}$ BrihadarnyakaUpanishadh, 1.4.14, Gita Press, Gorakhpur
} 


\section{ELK ASIA PACIFIC JOURNAL OF SOCIAL SCIENCE}

ISSN 2394-9392 (Online); DOI: 10.16962/EAPJSS/issn. 2394-9392/2015; Volume 5 Issue 1 (2018)

Indian philosophy means to act in accordance to 'Rta' or the cosmic order. It involves a sense of duty, right, responsibility, conduct, virtues and discipline of existence within the entire creation. Since, Indian Philosophy refuses to discriminate human, animals, trees, insects, birds and nature in their essence, most of the Vedic hymns, shlokas and prayers are general and not particular to any specie, religion, nation, cast or sex. An example of one such hymn comes from the Brihadarnyaka Upanishadh-

Om Sarve Bhavantu Sukhinah |

Sarve Santu Nir-Aamayaah ||

Sarve Bhadraanni Pashyantu

Maa Kashcid-Duhkha-Bhaag-Bhavet | Om Shaantih! Shaantih! Shaantih! $\|^{2} \mathrm{~A}$ dog, a pig, a fish is as much the Brahman in its essence as you and me. This explains why the 10 incarnations of Vishnu also have him incarnated as a fish, a pig and a tortoise.

Animals are considered sacred and divine and this throws light on why the dog is seen as a symbol of the Vedas in Shankara Digvijaya where Shiva appears as an outcast before AdiShankara along with his 4 dogs representing the 4 Vedas. Even in case of Dattatray, an Indian deity, the 4 dogs accompany him as the
4 Vedas. In the great epic Mahabharata, Yudhishthir, one of the 5 brothers/pandavas refuses to enter heaven without his dog. This also explains why Arjun was awe-struck when on his request Lord Krishna showed him his Vishwaroopa ${ }^{l}$. Arjuna saw a million of earths, seasons, animals, trees, birds, insects as the very body of Krishna.

Be it the Jatakas of the Buddhist, the Agamas of the Jainas, The Vedas, Epics or the Puranas, all are decorated with stories that supremely glorify nature, humans, animals, trees, bird, reptiles, mountains, rivers etc. Mount Kailash, Ashoka tree, Bodhi tree, Garuda-the bird, Vasuki- the snake, Shvanthe dog, Nandi- the bull, Kamdhenu- the cow, Hanuman- the monkey God, Airavat-the elephant, Krauncha- the rat, Ganga- the river, Suryadeva-the sun, Vayudeva-the air, Agnidev- the fire, Ram-the perfect human, Durga-the divine mother, Kinnars-the eunuch are all examples of the various manifestation of the non-dual, ultimate Supreme.

The following references from the Upanishads seal the non-dual essence of all that exists and rejects any superiority of humans as dominant beings:

\footnotetext{
${ }^{1}$ The Holy Bhagwad Gita Ch-11, Vishwaroopa Darshana
} 


\section{ELK ASIA PACIFIC JOURNAL OF SOCIAL SCIENCE}

ISSN 2394-9392 (Online); DOI: 10.16962/EAPJSS/issn. 2394-9392/2015; Volume 5 Issue 1 (2018)

'Ekoham Bahusyam'

(I am one and I shall become many)

-Taittiriya Upanishad ${ }^{1}$

'Ekạ̣ Devạ̣ Sarvabhūteṣu Gūọhạ̣ Sarvavyāpī

Sarvabhūtāntarātmā Karmādhyakṣạ̣

Sarvabhūtādhivāsaḥ Sākṣii Cetā Kevalạ̣

Nirguṇạ̣ Ca \|'

-Shvetashwatara Upanishad ${ }^{3}$

(One divine who alone is \& He indwells in every creature for He alone is the essence of the entire creation, He pervades all and is the silent witness of all our actions and is the womb of all things. He is also the Mighty witness to the thought of thought, breath of breath and all. He is the Absolute in whom mood is not nor any attribute.)

Thus, when a man starts seeing himself as a separate entity, he swells up with pride and thinks that he is meant to dominate all that is physically weaker than him. In his ignorance he forgets that even the smallest organism in this universe has a very big role to play.

Advaita-Vedanta represents a profound spirituality. In positive relation to the interest of ecology, it fosters values such as simplicity of life, frugality, non-violence, kindness and above all discarding 'duality' because there exists no 'two' says the Chandogya

Upanishad

Sarvam Khalu-Idam Brahman ${ }^{2}$

\footnotetext{
${ }^{1}$ Taittiriya Upanishad (3.1.1), Geeta Press, Gorakhpur ${ }^{3}$

Shvetashwatara Upanishad (6.11), Geeta Press, Gorakhpur

${ }^{2}$ Chandogya Upanishad 3.14, Geeta Press, Gorakhpur
}

(All is the Brahman)

S.Cromwell Crawford, states that the "Advaita-Vedanta has an ecological consciousness". ${ }^{3} \mathrm{He}$ further adds that, the concept of Brahman is an essential ingredient for an environmentally sound ethic, namely, 'reverence for nature'. According to him "The non-duality of Atman and Brahman, makes all creatures as the manifestation of the supreme", this gives Advaita-Vedanta a 'cosmic' outlook on life.

The following verses from the great epic Mahabharata clearly prohibit any kind of violence towards any creature be it an animal, human or the tiniest of insect and promotes ahimsa:

Ahimsa is the highest dharma. Ahimsa is the best tapas. Ahimsa is the greatest gift. Ahimsa is the highest self-control. Ahimsa is the highest sacrifice. Ahimsa is the highest power. Ahimsa is the highest friend. Ahimsa is the highest truth. Ahimsa is the highest teaching. ${ }^{45}$

\section{CONCLUSION}

At a time, when nature is under the wings of destruction, Advait-Vedanta philosophy

\footnotetext{
${ }^{3}$ The evolution of Hindu ethical ideals (Asian studies at Hawaii)Paperback 1982 by S. Cromwell Crawford

${ }^{4}$ Mahabharata 18:116.37-41, Mlbd

5 .Aitariya Up-3.3.7, Geeta Press, Gorakhpur

Brihadarnyak Up 1.4.10, Geeta Press, Gorakhpur
} 


\section{ELK ASIA PACIFIC JOURNAL OF SOCIAL SCIENCE}

ISSN 2394-9392 (Online); DOI: 10.16962/EAPJSS/issn. 2394-9392/2015; Volume 5 Issue 1 (2018)

alone can be mankind's savior. It is important for man to hold hands with sciences and development only till the point where it stands beneficial for all. It is time to understand that development cannot be merely a man's his birth right. Man has to take all animals, plants, rivers, mountains and every spec of the universe along with him for holistic development. It is time to learn to be free from the shackles of selfishness and use the natural resources for need and not for greed. It is important to realize that the self in me is the same self in you by pondering over the Mahavakyas of the Upanishads-

Prajnanam Brahman-Consciousness is Brahman ${ }^{4}$

\section{Aham Brahmasmi-I am the Brahman ${ }^{5}$}

\section{Tat Tvam Asi- You are That Brahman ${ }^{6}$}

Ayam Atman Brahman-The Self is the Brahman ${ }^{7}$

It is time we go back to the texts in order to understand them in the right light and evolve as kinder, enlightened and responsible beings holding in our heart love for all. It is only when we see the self in all and all in the self that we will be the protector and the protected. We thus will be able to construct a world where diversity of names and forms will be united with one single thread of divine consciousness. In our journey to realize the self in all and all in the self, we have to walk on the path of non-duality which in Indian tradition is called "Advaita Vedanta".

\section{REFERENCES:}

1. The Rig Veda, Gita Press, Gorakhpur

2. Yajur Veda, Gita Press, Gorakhpur

3. Shiva Mahapuran, Gita Press, Gorakhpur

4. The Holy Bhagwad Gita,, Gita Press, Gorakhpur

5. Brihadarnyaka Upanishadh, Gita Press, Gorakhpur

6. Taittiriya Upanishad, Geeta Press, Gorakhpur

7. Shvetashwatara Upanishad, Geeta Press, Gorakhpur

8. Chandogya Upanishad, Geeta Press, Gorakhpur

9. The Evolution of Hindu Ethical Ideals (Asian Studies at Hawaii) Paperback -1982 by S. Cromwell Crawford

10. Atharva-Vedas, Geeta Press, Gorakhpur

11. Mahabharata, Mlbd

12. Aitariya Up, Geeta Press, Gorakhpur

13. BrihadarnyakUp, Geeta Press, Gorakhpur

14. ChandogyaUp, Geeta Press, Gorakhpur

15. Brihadarnyak Up, Geeta Press, Gorakhpur 